\title{
KANSALAIS- JA TYÖVÄENOPISTO -OPISKELUN JUURET AIKUISOPISKELIJAN ELÄMÄSSÄ
}

"Aikuisopiskelun juuret löytyivät opiskelijoiden elämäntilanteista. Jokainen elämäntilanne on erilainen, mutta sisältää samankaltaisia rakenteellisia jäsennyksiä. Elämän jatkuvuus pitää yllä pysyvyyttä opiskelijoiden elämässä. Jotkut opiskelijat pitävät yllä pysyvyyttä opiskelun kautta; jotkut toiset opiskelijat hakevat muutosta elämäänsä opiskelun avulla. Kummassakin tapauksessa opiskelijat pyrkivät hallitsemaan omaa elämäänsä. Elämän hallinta voi lähteä joko omasta itsestä tai ulkoisesta todellisuudesta", Katri Poutanen ja Antti Kauppi kirjoittavat.

Artikkeli perustuu tutkimukseen, jossa on selvitelty pitkäaikaisten työväenopistossa opiskelleiden opiskelun juuria. Vaikka useimmat aikuisopiskelijat pitävät sisällään piirteitä useimmista opiskelijatyypeistä, voidaan kuitenkin pitkäaikaisopiskelijoista erottaa neljä perustyyppiä: tavoitteelliset opiskelijat, harrastusopiskelijat, kompensaatioopiskelijat ja ajan täyttämiseen tähtäävät opiskelijat.

\section{Aikuiskoulutukseen osallistuminen tutkimusongelmana}

Aikuisten osallistuminen koulutukseen on jo pidempään ollut keskeisiä kysymyksiä sekä aikuiskoulutuksen kentällä että tutkimukses. sa. On mietitty, mikä saa aikuisen osallistumaan koulutukseen - miksi jotkut osallistuvat ja jotkut eivät, mitkä seikat tukevat osallistumista ja mitkä estävät, millaisia tavoitteita aikuiset asettavat opinnoilleen, miksi he jatkavat opintojaan ja miksi keskeyttävät. Kysymyksiä on monia.

Osallistumisen syitä ja osallistumisesteitä on 210 tutkittu paljon. Tutkimukset ovat kuitenkin ol- leet usein yksipuolisia. Aulis Alanen (1985, 120) kritisoikin osuvasti osallistumistutkimusta toisaalta sosiaalideterminismistä ja toisaalta yksipuolisesta psykologismista. On tutkittu joko yhteiskunnan rakennetekijöitä tai persoonallisuustekijöitä huomioimatta, että aikuinen osallistuu opiskeluun aina sekä omana persoonanaan että sosiaalisen ympäristönsä muodostamissa puitteissa. Osallistumistutkimukset ovat myös ehkä liiankin kanssa sortuneet metodiseen empirismiin, tilastomatemaattiseen numeropeliin, samalla laiminlyöden teoreettisen jäsentelyn ja analysoinnin.

Aikuiskoulutukseen osallistumista on myös yleensä lähdetty kartoittamaan koulutuksen perspektiivistä. Nimenomaan aikuiskoulutukseen osallistuminen on otettu lähtökohdaksi, 
vaikka aikuisen elämäntilanteessa on useita erilaisia vaihtoehtoja, joihin osallistumishalukkuus voi kohdistua. Olisikin ehkä syytä voimakkaammin lähteä jäsentämään aikuisen elämäntilannetta ja kysyä, miten osallistuminen opintoihin kumpuaa elämisen dynamiikasta.

Artikkelissa lähdetään purkamaan osallistumisproblematiikkaa aikuisten elämäntilanteista käsin. Aikuisten osallistumissyitä tarkastellaan pitkäaikaisten työväenopisto-opiskelijoiden näkökulmasta. Artikkeli rakentuu kansalais- ja työväenopistojen opetuksen laadun kehittämisprojektin (ks. Kauppi 1988) puitteissa tehdylle opinnäytetyölle (Kankanen (nyk. Poutanen) 1990).

\section{Pitkäaikaiset aikuisopiskelijat tutkimuksen kohteena}

Tutkimuksen kohderyhmän muodostivat kaksikymmentäyksi 40-59 -vuotiasta opiskelijaa Kotkan työväenopistossa lukuvuonna 1988-89. Haastatellut opiskelijat olivat opiskelleet vähintään viisi vuotta opistossa. He olivat mukana vähintään kahdessa opintoryhmässä ja opiskelivat kieliä, taideaineita tai käytännön aineita. Tutkimuksen kohderyhmää yhdisti pitkäaikainen opiskelu Kotkan työväenopistossa. Taustoiltaan opiskelijat olivat hyvin erilaisia. Kohderyhmästä $2 / 3$ opiskeli kieliä ja muut opiskeltavista aineista jakautuivat taideaineisiin ja käytännön aineisiin.

Keski-ikäisten kokemien elämäntilanteiden ja -muutosten kautta haluttiin arvioida opiskelun merkitystä heidän elämässään. Keski-iässä yksilö usein arvioi menneisyyttään ja nykyisyyttään, muovaa arvojaan ja asenteitaan ja tarkistaa minäkäsitystään. Keski-ikä on itsereflektoinnin aikaa; omaa minää havainnoidaan ja omaa elämää arvioidaan uudelleen (ks. esimerkiksi Levinson 1978, 192; Merriam 1978, 39-54).

Tutkimuksen tarkoituksena oli selvittää aikuisopiskelijoiden lähtökohtia työväenopistoopiskelulleen. Aikuisen oppimista suuntaa elämän kokonaistilanne; elettävä elämänvaihe, sen objektiiviset puitteet ja koetut ongelmat. Aikuisen intressit nivoutuvat olosuhteisiin, jotka vaikuttavat hänen toimintaansa ja sen muotoutumiseen.

Haasteeksi tutkimukselle muodostuivatkin aikuisen elämäntilanteesta nousevat opiskelun aihiot. Opiskelu ei tapahdu tyhjiössä, vaan se herää elämänhistoriasta ja sen kulloinkin aikuisen eteen asettamista vaatimuksista ja mahdollisuuksista. Keskeisiksi tutkimusongelmiksi nousivat:

- miksi pitkäaikaiset aikuisopiskelijat olivat alunperin aloittaneet opiskelunsa työväenopistossa?

- miksi opiskelusta oli muodostunut osa heidän jokapäiväistä elämäänsä?

\section{Kertomukset elämästä tutkimusaineistona}

Tutkimuksen strategiana oli suunnata aikuisopiskelijoita muistelemaan elämäntilanteitaan ja rakentamaan kokemusperäistä analyysiä omasta opiskeluhistoriastaan. Kvalitatiivinen tutkimushaastattelu kohdistuu yksilön omiin kokemuksiin ja hänen tulkintoihinsa niistä. Haastattelut rakentuvat tutkittaville teemoille, joiden avulla yksilö jäsentää elämäntilantilanteitaan ja kokemuksiaan. Tämä vaatii tutkijalta kertomuksien kuuntelua myös "rivien välistä". (ks. Kvale 1983, Leahey 1989).

Lähtökohtana tutkimuksessa pidettiin aikuisen omaa kertomusta opiskelustaan. Tutkimusaineiston analyysi perustuikin aineistosta nousseille näkökulmille - valmista teoriaa ei lähdetty testaamaan. Teoreettinen viitekehys työväenopisto-opiskelun juurista opiskelijan elämässä muotoutui tutkimuksen kuluessa.

Tutkimushaastattelut koostuivat seuraavista teemoista:

A. opiskeluhistoria

B. elämäntilanne työväenopisto-opiskelua aloitettaessa

C. opiskelun tavoitteet opiskelua aloitettaessa

D. käsitys itsestä opiskelijana (kyvyt)

E. ympäristön tuki opiskelulle

F. oman elämäntilanteen kokeminen

G. työväenopisto-opiskelun kokeminen

\section{AIKUISOPISKELIJA TAVOITEHAKUINEN HARRASTAJAKO?}

\subsection{Tyypilliset aikuisopiskelijat onko heitä?}

Roos (1988, 201) näkee, että kvalitatiivisessa analyysissa voidaan käyttää karkeasti kahta 
perusstrategiaa: tematisointia ja tyypittelyä. Tematisointi on välttämätöntä aineiston analy. soinnissa, mutta sen avulla on vaikeaa esittää tuloksia havainnollisesti. Tyypittely puolestaan antaa mahdollisuuden kuvata tutkimuksen tuloksia havainnollisemmin ja kansantajuisemmin.

Tyyppiin on sisällytetty kaikkea sellaista, mitä jossain erillisessä havaittavassa yksilössä ei esiinny. Tyypit on rakennettu näin ollen perus. tuen yleistyksille useita yksilöitä yhdistävistä piirteistä. Yksilöt voidaan sijoittaa typologian muodostamiin puitteisiin vain tekemällä hieman väkivaltaa heidän yksilöllisille kokemuksilleen ja ajatuksilleen. Tutkimuksessakin useat aikuisopiskelijat pitivät sisällään piirteistä useammista tyypeistä. Selkeästi tutkimusaineistosta nousi kuitenkin esille neljä keskeistä opiskelijatyyppiä.

1. Tavoitteelliset opiskelijat

2. Harrastusopiskelijat

3. Kompensaatio-opiskelijat

4. Ajan täyttämiseen tähtäävät opiskelijat

\subsection{Tavoitteelliset opiskelijat}

Tavoitteellisilla opiskelijoilla oli useilla pitkä opiskeluhistoria ja myönteisiä kokemuksia opiskelustaan. Tästä syystä heidän oli helppoa hakeutua aikuisenakin opiskelun pariin. Opiskelu miellettiin hyödyllisenä toimintana eikä opiskelun aloittaminen tuottanut vaikeuksia. Se oli valmiiksi tuttu tapa.

Opiskelun resurssinomaisuus tuli selvästi esille. Sen avulla saatiin tietoja ja taitoja, joita hyödynnettiin esimerkiksi työelämässä. Opiskelun jatkuttua pidempään opiskelijoiden oli vaikea muotoilla sille selkeitä tavoitteita. Opiskelusta oli tullut osa sisäistä elämänhallintaa - pyrkimystä oman kehittymisen hallitsemiseen. Opiskelu oli näille opiskelijoille niin omaan elämään kuuluva tapa ettei sitä enää osattu kriittisesti pohdiskella.

"Minulla tämä alkoi tavoitteena pätevyyden lisääminen... Suoritin Kotkan kesäyliopistossa englannin tuntiopettajapätevyyden... Sain opettaa sitten englantia ala-asteella... Mä olen muuten vaan ollut kiinnostunut englannista... Se oli harrastusta aluksi... Ta. voitteet tulivat, kun huomasi, että tätä voi käyttää hyödyksi... ja tulihan siitä palkkaakin lisää... jatkoin englantia opistossa... Työväenopisto oli sellainen kiintopiste uudella voitetta enää... Se on vaan se ajankulu ja uusiin ihmisiin tutustuminen siellä... ja mie. lenkiinto kieleen... Jos vain istuisi vapaaajalla, eikä siitä olisi mitään tulosta... niin oma arvostus varmasti laskisi... Kielten opiskelusta saa tyydytystä, kun oppii puhumaan sitä kieltä, keskustelemaan... tulemaan vieraiden ihmisten kanssa toimeen... En oikeastaan osaisi olla ilman opiskelua, kun minulla on niin paljon vapaa-aikaa... Se on sellainen harrastus, joka antaa sisältöä elämään ja kun on niitä läksyjäkin, niin niitä tehdessä menee niin mukavasti aika päivisin..." (58-vuotias mies)

Opiskelu oli muodostunut tavoitteellisille opiskelijoille rutiininomaiseksi toimintakäytännöksi. Se oli näille opiskelijoille arvokas ajankäyttötapa, joka antoi sekä hyötyä että sisältöä elämään. Opiskelusta oli muodostunut vähitellen elämäntapa, joka antoi lisää sisältöä elämään vielä eläkeiässäkin. Opiskelun koetut vaikutukset omaan elämään olivat siis olleet vahvat.

\subsection{Harrastus -opiskelijat}

Harrastusopiskelijoilla opiskelun aloittaminen liittyi sosiaalisiin kontakteihin. Ystävien ja tuttujen kanssa oli totuttu tekemään ja puuhailemaan, joten tällainen toiminta oli luonnollinen osa elämää. Harrastuksen kautta varsinkin naiset totesivat saaneensa omaa aikaa kodin ulkopuolelta.

"Tuli halu harrastaa noin 33-vuotiaana... tarve, että jotain muutakin täytyy olla kuin työssäkäyntiä, lastenhoitoa ja ulkoilua...Olen aina ollut kiinnostunut kielistä... lähdettiin sitten ystävättären kanssa espanjaa lukemaan työväenopistoon... Mulle oli tärkeetä ja on edelleenkin, että on joku harrastus, ja sen voi sitten käyttää esimerkiksi kielten opiskeluun... Opiskelu ei mulla ole koskaan ollut sidoksissa mihinkään päämäärään... tuottaa vaan mielihyvää, kun voi käyttää ja ymmärtää kieltä... ja liikunnasta saa hyvää oloa... Ystävättären kanssa tuli lähdettyä voimistelemaankin... Minut tarvitsee aina potkia johonkin nähtävästi..." (45-vuotias nainen)

Harrastusopiskelijat jatkoivat opiskelua ulkoisen elämänhallinnan takia. Heillä kiinnostus opiskeluun oli ulkokohtaisempaa kuin tavoitteellisilla opiskelijoilla. Harrastusopiskelijoille opiskelu merkitsi ystävien kanssa oloa, sosiaalista kanssakäymistä; se oli pyrkimystä ulkoisten olosuhteiden hallitsemiseen. 
"Tämä on leppoisampi tapa opiskella... päällepainava tyyli ja kireä tahti eivät sovi minulle... Tänne voi mukaan tulla istuskele. maan, vaikkei aina ihan kärryillä olisikaan... Minulla on sellainen platoninen kiinnostus kieliin, eikä haittaa vaikka niitä ei aina tai juuri ollenkaan tulisi käytettyä... Tää on ollut aina vaan harrastusta..." (43-vuotias mies)

Opiskelu ylläpiti elämän organisointiin sitoutuneita rutiineja: säännöllisesti kokoontuvat opintopiirit antoivat harrastusopiskelijan ulkoiselle elämänhallinnalle säännöllisesti toistuvat puitteet.

"Tuntuu vaikealta rikkoa rutiineita... Siksi täällä (opistossa) onkin... Avainkysymys siinä tulee syyllisyydentunteesta... Sitä tavallaan niinku pettää ryhmän... Siitä on tullut rutiini... Se (opiskelu) alkaa joka syksy... aina... Tiedän aina, että mulla on maanantaina englanti, tiistaina jumppa jne... jo etukäteen... Kuitenkin sinne on ihan kiva mennä... Ruuanlaitto ei tunnu mukavalta töiden jälkeen..." (40-vuotias nainen)

\subsection{Kompensaatio -opiskelijat}

Kompensaatio-opiskelijat olivat aloittaneet opisto-opiskelunsa tietoisella halulla vaikuttaa omaan elämäänsä. He olivat kokeneet itsensä ahdistuneiksi omissa elämäntilanteissaan ennen opistoon tuloaan. Opiskelun käynnisti eräänlainen transformaatio omassa elämäs sä. (Tässä tarkoitetaan transformaatiolla elämän rakenteisiin ulottuvaa laadullista muutosta. Kysymys ei ole vain siitä, että elämään tulee jokin uusi asia. Transformaatio olennaiselta osaltaan murtaa elämän perustana olleita rutiineja ja pakottaa muovaamaan laadullisesti erilaisia toimintakäytäntöjä.)

Opiskelusta lähdettiin hakemaan haastetta tai korviketta omaan elämään. Aikuinen oivalsi sisäisen elämänhallinnan olevan hänestä itsestään kiinni. Transformaatio, esimerkiksi vaikea avioero, ei lamauttanut aikuista vaan hän oivalsi elämän hallinnan riippuvan hänen omasta toiminnastaan.

"Tästä on kaksikymmentä vuotta, kun mie tulin ekan kerran työväenopistoon... Se alko silloin, kun mie muutin Kotkaan asumuseroon... Kun nuorempana on kauheesti huolia ja ongelmia... niin ei sitä kerkiä oikein ajattelemaan... ei ole resursseja... Sitä on niinkuin kiinni lapsiin ja työhön... johon- kin... Mie olen alkanut elää taas... ennen mie olin vaan... elin muitten ehdoilla... Se sisu tuli eron jälkeen, että sai eron... Mulla on kauhee halu oppii kaikkee... Mie olen ollut valtavan ujo ja arka nuorempana... On tullut jonkinlaista varmuutta, ettei nyt kauheesti tartte pelätä ihmisiä... Ihmisen pitäis aina opiskella... " (42-vuotias nainen)

Kompensaatio-opiskelijat halusivat sekä muuttaa toimintakäytäntöjä omassa elämäs sään että luoda toisenlaista kuvaa itsestään. Opiskelu antoi sisäisen elämänhallinnan tunnetta - sillä rakennettiin oman minän sisäistä eheyttä. Samalla se toimi oman elämän särökohtien paikkaajana. Opiskelun avulla haluttiin luoda uudenlaista kuvaa omasta itsestä ja maailmasta. Oman elämän ohjaukseen tarvittiin uusia arvoja ja toimintakäytäntöjä.

\subsection{Ajan täyttämiseen tähtäävät opiskelijat}

Ajan täyttämiseen tähtääville opiskelijoille oli jäänyt erilaisten transformaatioiden joh dosta aikaa omassa elämässään. Tällaisia transformaatioita olivat esimerkiksi sairaseläkkeelle jääminen, kotiäidiksi joutuminen tai muutto Kotkaan. Muutokset elämässä synnyttivät ajallisesti tyhjiä aukkoja, joita haluttiin täyttää työväenopisto-opiskelulla. Kimmoke opiskelun aloittamiselle tuli opiskelijan ulkopuolelta, muutostilanteesta. Aikataulukehyk sien säilyttäminen elämässä opiskelun avulla on ollut monille opiskelijoille ollut tärkeää myöhemminkin, kun he ovat jääneet työelämästä pois. Ajan täyttämiseen tähtäävillä opiskelijoilla oli tietoinen halu hakea "päivien täyttöä opistosta" eivätkä he ajautuneet opistoon kuten harrastus-opiskelijat.

\begin{abstract}
"Kun joutu sairaseläkkeelle... niin kävi miettimään, että jotain pitäis' harrastaa... ettei ihan vaan laiskottele... Itsellään oli sellainen tunne, että haluaa tehdä jotain, kun pystyy... Olin muuttanut juuri nykyisen poikakaverini luo Kotkaan... Sitä kun katseli, että ystävät menestyvät ja pääsevät korkeisiin asemiin, niin tunsi, että täytyy itsekin opiskella... ettei tuntisi itseään ihan nollaksi toisten joukossa... että osaa jutella ihmisten kanssa..." (50-vuotias nainen)
\end{abstract}

Tutkimusaineistosta sai vaikutelman, etteivät opiskelijat hakeutuneet niinkään opiskelemaan jotakin tiettyä ainetta kuin täyttämään muuten ajallisesti tyhjiä aukkoja elämässään. Ajan täyttämiseen tähtäävät opiskelijat suhtautuivat opiskeluun ulkokohtaisesti. Opiskelu oli 
väline ulkoisen elämänhallinnan lisäämiseen.

"Vuonna -76 jäin eläkkeelle... ja ajattelin etten jää sängynpohjalle lojumaan, vaan lähden työväenopistoon... Mulla oli ennen vanha kamera ja se jäi siihen seinälle roikkumaan filmi sisässä... Sit ajattelin, että lähden valokuvauskerhoon opistoon... että on vähän vaihtelua, ku' ei oo paljon muutakaa... Se on tärkeintä siinä, että on jotain tekemistä...on parempi käydä siellä... muuten olisin vaan kotona enkä tekis' sitte yhtään mitään..." (58-vuotias mies)

Säännöllinen osallistuminen työväenopiston kursseille oli ajan täyttämiseen tähtääville opiskelijoille yksi elämänhallinnan keino. He olivat tyytyväisiä siitä, että voivat käyttää vapaa-aikaansa opiston piirissä. Heidän elämässään oli tiettyjä instituutioita kuten opisto, jonka olemassaolo antoi heidän elämäänsä yhden säännöllisen kiinnekohdan.

\subsection{Opiskelija- tyyppitaulukko}

Taulukossa 1 esitetään tutkimusaineistosta esiin nousseet opiskelijatyypit ja tutkimushaastatteluiden teemat. Teemat saavat eri painotuksia kullakin opiskelijatyypillä riippuen hänen omasta kertomuksestaan.

Tavoitteellisilla opiskelijoilla opiskeluhistoria (teema A) oli opinnollisempi kuin muilla opiskelijatyypeillä. Kolmella viidestä tavoitteellisesta opiskelijasta oli korkeakouluopintoja. Opiskelu koettiin itsessään miellyttävänä ja siihen oli totuttu suhtautumaan tavoitteellisesti.

Ajan täyttämiseen tähtäävillä opiskelijoilla korostui "elämäntilanne opiskelua aloittaessa" (teema B). Näitä opiskelijoita yhdisti ulkoinen elämänmuutos opiskelun aloitusvaiheessa. Oman ajan hallinta tuli tärkeäksi mm. opiskelijan joutuessa eläkkeelle tai muuttaessa asuinpaikkaa.

Opiskelun aloitusvaiheessa tavoitteet erosivat kaikilla opiskelijatyypeillä (teema C). Tavoitteelliset opiskelijat pitivät tavoitteita opiskelun aloitusvaiheessa keskeisinä; he halusivat saada opiskelun kautta lisää pätevyyttä mm. työhönsä. Harrastusopiskelijoilla tavoitteet eivät olleet selkeitä; he enemmänkin ajautuivat opistoon. Kompensaatio-opiskelijoille oli puolestaan emansipatorinen intressi, pyrkimys vapautua nykyisen elämän kahleista, tärkeä opistoon tullessaan. Ajan täyttämiseen tähtää- vät opiskelijat puolestaan korostivat tavoitteenaan lähinnä päivien täyttöä mielekkäällä toiminnalla.

Teema D, "käsitys itsestä opiskelijana", tuli esille merkityksellisimmin kompensaatio-opiskelijoilla, jotka hakivat oman elämänsä sisäistä hallintaa opiskelunsa kautta.

"Ympäristön tuki opiskelulle" (teema E) nousi esille keskeisimmin harrastus-opiskelijoilla. He kokivat opiskelunsa läheisesti sosiaa. liseen ympäristöönsä nivoutuvana - ilman ystäviä ei kenties osallistuttaisikaan opiskeluun.

Kaikki opiskelijatyypit kokivat opiskelunsa kuuluvan lujasti nykyiseenkin elämäänsä (teema F). Opiskelusta oli tullut ajan myötä merkittävä elämään kiinteästi kuuluva käytäntö. Opiskelun toistuvuus vuodesta toiseen koettiin tuttuna ja turvallisena asiana elämässä. Tämän takia viimeinen teema "työväenopistoopiskelun kokeminen" (teema G) olikin kaikille tyypeille merkityksellinen. Opisto-opiskelusta oli tullut opiskelijoille elämäntapa, joka toi elämään mielekästä toimintaa.

\section{Pysyvyys, muutos ja elämänhallinta}

Tutkimusaineiston perusteella aikuisopiskelun juuret löytyivät opiskelijoiden elämäntilanteista. Jokainen elämäntilanne on erilainen, mutta sisältää samankaltaisia rakenteellisia jäsennyksiä. Elämän jatkuvuus pitää yllä pysyvyyttä opiskelijoiden elämässä. Jotkut opiskelijat pitävät yllä pysyvyyttä opiskelun kautta; jotkut toiset opiskelijat hakevat muutosta elämäänsä opiskelun avulla. Kummassakin tapauksessa opiskelijat pyrkivät hallitsemaan omaa elämäänsä. Elämän hallinta voi lähteä joko omasta itsestä tai ulkoisesta todellisuudesta.

Pysyvyys rakentuu rutiineille - siihen miten päivästä päivään tehdään asioita. Rutiinien avulla järjestetään toimintoja elämässä ja ne saavat ajankäytöllisesti tietyt puitteet. Yksilö tietää, mitä hänen elämäänsä kuuluu ja miten hän hallitsee asioitaan ja toimintaansa. Giddens (1984) kutsuu tätä ontologiseksi turvallisuudeksi. Giddensin (ks. 1979, 1984a, 1984b, Cohen 1989, Ilmonen 1990) analyysi antaa perustan selvittää elämäntilanteiden ja siellä vallitsevien toimintakäytäntöjen uusinta. mista ja muuttamista rakenteiden muodostamissa puitteissa. 
OPISKELIJATYYPPITAULUKKO

$\begin{array}{llll}\text { 1. Tavoit- } & \text { 2. Harras- } & \text { 3. Kompen- } & \text { 4. Ajantäyttä- } \\ \text { teellinen } & \text { tus-opiske- } & \begin{array}{l}\text { saatio- } \\ \text { opiskelu }\end{array} & \begin{array}{l}\text { miseen tähtää- } \\ \text { vä opiskelu }\end{array}\end{array}$

A. Opiskeluhistoria

B. Elämäntilanne opiskelua aloittaessa

C. Opiskelun tavoitteet aloittaessa

D. Käsitys itsestä opiskelijana

E. Ympäristön tuki opiskelulle

F. Oman elämäntilanteen kokeminen

G. Työväen-
opisto
opiskelun
kokeminen

\begin{tabular}{|c|c|c|c|}
\hline \multirow[t]{2}{*}{$\begin{array}{l}\text { opinnollisempi } \\
\text { muihin } \\
\text { tyyppeihin } \\
\text { verrattuna }\end{array}$} & & & \\
\hline & & & $\begin{array}{l}\text { elämäntilanne } \\
\text { korostui; } \\
\text { ulkoinen } \\
\text { elämänmuutos }\end{array}$ \\
\hline \multirow[t]{3}{*}{$\begin{array}{l}\text { tavoitteet } \\
\text { keskeisiä; } \\
\text { halu saada } \\
\text { lisää pätevyyttä }\end{array}$} & $\begin{array}{l}\text { tavoitteet } \\
\text { eivät } \\
\text { selkeitä } \\
\text { - ajautuva }\end{array}$ & $\begin{array}{l}\text { emansipato- } \\
\text { rinen } \\
\text { intressi }\end{array}$ & $\begin{array}{l}\text { päivien } \\
\text { täyttöä }\end{array}$ \\
\hline & & $\begin{array}{l}\text { opiskelun } \\
\text { kautta oman } \\
\text { elämän } \\
\text { hallintaa }\end{array}$ & \\
\hline & $\begin{array}{l}\text { sosiaalinen } \\
\text { lähtökohta: } \\
\text { ystävän kanssa } \\
\text { opistoon }\end{array}$ & & \\
\hline $\begin{array}{l}\text { opiskelua ei } \\
\text { hellitä } \\
\text { eläkkeelle } \\
\text { jäätyäkään }\end{array}$ & $\begin{array}{l}\text { opiskelu antoi } \\
\text { tietoisuuden, } \\
\text { mitä on } \\
\text { ohjelmassa } \\
\text { viikolla }\end{array}$ & $\begin{array}{l}\text { nyt on } \\
\text { enemmän } \\
\text { aikaa itselle }\end{array}$ & $\begin{array}{l}\text { ajankäytön } \\
\text { kokeminen } \\
\text { edelleen } \\
\text { tärkeää }\end{array}$ \\
\hline $\begin{array}{l}\text { "opiskelu } \\
\text { antaa } \\
\text { sisältöä } \\
\text { elämään" }\end{array}$ & $\begin{array}{l}\text { "tää } \\
\text { harrastaminen } \\
\text { on elämäntapa" }\end{array}$ & $\begin{array}{l}\text { "kauheasti } \\
\text { halua } \\
\text { henkisesti } \\
\text { kehittävään" }\end{array}$ & $\begin{array}{l}\text { "opiskelu } \\
\text { kuuluu ihan } \\
\text { kuvaan } \\
\text { elämässä" }\end{array}$ \\
\hline
\end{tabular}

("Työväenopisto-opiskelun juuret aikuisopiskelijan elämässä" -opinnäytetyö, Kankanen 1990.)

Toimijat ja rakenne muodostavat dualiteetin. Rakenteen dualiteetilla Giddens tarkoittaa, että rakenne on sekä toiminnan väline että tuotos. Rakenne ei ole olemassa ilman ihmisten toimintaa. Rakenne mahdollistaa tai rajoittaa ihmisten toimintaa. Yksilöt uusintavat toimiessaan sosiaalisen elämän rakenteellisia piirteitä. Uusintaessaan rakenteellisia piirteitä yksilöt uusintavat myös olosuhteita, jotka mahdollis- tavat kyseisen toiminnan. Työväenopiston olemassaolo paikkakunnalla tarjoaa mahdollisuuden osallistua opiskeluun siellä. Työväenopisto taas instituutiona uusiintuu sillä, että siellä opiskellaan jatkuvasti. Opiskelijat uusintavat toimintansa kautta paitsi omaan elämäänsä kuuluvia käytäntöjä myös yleisemmin esimerkiksi opiston toimintakäytäntöjä. 
Vuorovaikutus on kontekstuaalista; se tapahtuu ajassa ja paikassa ja siihen liittyvät puitteet, toimijat ja viestintä heidän välillään (Giddens 1984, 373). Aika ja tila säätelevät toiminnan mahdollisuuksia niin opiskelijan kuin opistonkin kannalta. Opisto ja siellä opiskelu ovat eri konteksteja - opiston toiminta rakentuu ensi sijassa opettajien toiminnan kautta; opiskelu puolestaan rakentuu opiskelijoiden toiminnan ympärille ja suurelta osin opiston ulkopuolelle. Jokainen opiskelija tuo oman elämänsä tietopohjan ja elämänvaiheensa kokemuksineen mukaan opistoon.

Elämänmuutokset ovat luonnollinen osa aikuisen elämää. Muutos saattaa heijastua toimintakäytäntöihin uudenlaisena elämänrakenteen jäsennyksenä, transformaationa. Tällöin se edellyttää rutiinien rikkomista (esimerkiksi Mezirow 1990). Toisaalta tutut rutiinit elämässä murtuvat muutoksia kohdatessa, ja silloin edessä on haasteita ja tehtäviä, jotka tulisi selvittää. Muutoksia voivat olla esimerkiksi naimisiinmeno, lapsen syntymä, työpaikan vaihto, työttömyys tai eläkkeelle jääminen. Rutiinien psykologinen luonne tulee ilmi juuri tilanteissa, joissa totutun elämän mallit heikkenevät tai murtuvat (Giddens 1984, 60). Muutostilanteet voivat saada yksilön reflektoimaan kriittisesti elämäänsä. Opiskelu voi olla yksi haasteiden tai muiden eteentulleiden tehtävien ratkaisuyritys.
Aineellinen ja sosiaalinen turvallisuus ovat lisääntyneet nykyihmisen arkielämässä, niin että ihminen voi haluta vastakohtia tai muutoksia elämäänsä. Roosin $(1988,50)$ mukaan näihin uusiin ilmiöihin elämäntapojen kehityksessä liittyy tärkeänä osana elämän hallitsemisen elementti: "järjestetään itse elämää, synnytetään itse itselle vaikeuksia". Kontrastia arkielämälle voidaan etsiä opiskelusta. Ajan järjestäminen opiskelulle ja sen jatkaminen opistossa on yksi tapa oman elämän hallintaan.

Kaikilla opiskelijatyypeillä oli vahva halu säilyttää ja uusintaa kerran syntynyt toimintakäy. täntö, opiskelu elämässään. Opintoaktiivisuus kehittyi opiskelijoiden omasta elämästä. Täten ei syitä opiskelun jatkumiselle voitu niinkään löytää työväenopistosta tai siellä opetettavista aineista. Opiskelua jatkettiin elämänhallinnan takia. Elämän pysyvissä vaiheissa opiskelusta oli elämäntapa ja ulkoisen elämänhallinnan merkitys korostui. Elämän muutosvaiheissa taas korostui sisäisen elämänhallinnan merkitys ja opiskelu oli silloin oppimisen pontimena.

Sisäinen elämänhallinta oli tutkimuksen kohderyhmällä pyrkimystä oman kehittymisen hallitsemiseen. Ulkoinen elämänhallinta oli taas pyrkimystä ulkoisten olosuhteiden hallitsemiseen. Aineistosta nousseiden tyyppien perusteella voitiin muodostaa seuraavanlainen nelikenttätaulukko.

\section{Taulukko 2. OPISKELIJATYYPPIEN NELIKENTTÄ}

\begin{tabular}{l|l|l|}
\multicolumn{1}{c}{} & \multicolumn{1}{c}{ Rutiinit } & \multicolumn{1}{c|}{ Transformaatiot } \\
\cline { 2 - 3 } $\begin{array}{l}\text { Sisäinen } \\
\text { elämänhallinta }\end{array}$ & $\begin{array}{l}\text { tavoitteellinen } \\
\text { opiskelu }\end{array}$ & $\begin{array}{l}\text { kompensaatio } \\
\text { opiskelu }\end{array}$ \\
\cline { 2 - 3 } $\begin{array}{l}\text { ulkoinen } \\
\text { elämänhallinta }\end{array}$ & $\begin{array}{l}\text { ajan täyttä- } \\
\text { miseen tähtäävä } \\
\text { opiskelu }\end{array}$ \\
\hline opiskelu
\end{tabular}

Opiskelijatyyppien nelikenttä kuvaa opiskelun suhdetta opiskelijan elämäntilanteeseen. Ei ole kuitenkaan mielekästä tyypitellä opiskelijaa vain yhteen tyyppiin - jokainen opiskelija omaa piirteitä useammista tyypeistä, painotuserot vain vaihtelevat. On myös keskeistä havaita, että opiskelijan elämäntilanteen muut- tuessa myös hänen painotuksensa taulukossa muuttuu. Niinpä esimerkiksi tutkimamme aikuisopiskelijat sijoittuivat eri tavoin taulukkoon opiskelua aloittaessaan. Haastatteluja tehtäessä oli useimmilla opiskelu muuttunut rutiininomaiseksi osaksi omaa elämää ja lähes kaikki painottivat harrastusopiskelun aluetta. 


\section{Jatkokysymyksiä}

Osallistumistutkimus on paitsi yleisesti myös erityisesti kansalais- ja työväenopistojen opetuskäytäntöjen kehittämisen kannalta mielenkiintoinen alue. Siinä tehdään loppujen lopuksi sekä opiskelun syiden kartoittamista että eräänlaista markkinatutkimusta. Kysytäänhän siinä toisaalta miksi aikuisopiskelijat opiskelevat sekä toisaalta millainen koulutus käy kaupaksi. Tällaisten kysymyksenasettelujen kautta se tavalla tai toisella ohjaa opistojen toimintakäytäntöjen kehittämistä. Artikkelin perustal. ta voidaan nostaa esille haasteina kehittämis. työhön joitain kysymyksiä.

Rakennetaanko jatkuvasta koulutuksesta opistoissa elämäntapaa vai muutoksen hallin. nan välinettä? Millaiseen elämänhallintaan opistojen opetus ohjaa? Onko opetuksen tavoitteena pysyvyys vai muutos? Opetetaanko opistossa oppiainetta vai elämänhallintaa? Miten oppiaineet integroituvat toimintakäytäntöihin opiston ulkopuolella?
Pitääkö opiston pyrkiä asettamaan opiskelulle tietoinen tavoite, jolloin suosittaisiin joita. kin opiskelijatyyppejä toisten kustannuksella? Suositaanko jo tällä hetkellä tiettyjä opiskelija. tyyppejä, kun huomioidaan opiskelijarakenne - suuri osa opiskelijoista on keski-ikäisiä hyvin toimeentulevia naisia. Miten suosiminen tavalla tai toisella istuu opistojen tehtäväkäsitykseen ja tehtäväkuvaan? Entä miten suosiminen heijastuu opiskelijarakenteeseen ja opiskelijamäärään?

Pitääkö jokaiselle opiskelijalle tarjota hänen omasta elämäntilanteestaan lähtevää mahdol. lisuutta opiskella? Miten tällainen opiskelu mahdollistuisi nykyisenkaltaisilla kursseilla kerran viikossa kaksi tuntia kerrallaan usein suuressa ryhmässä? Miten erilaiset tiedonintressit, joita eri opiskelijatyypeillä on, heijastuvat opistojen opetuksessa? Miten opistossa rakennetaan opetuksen ja elämäntilanteen kytkentä? Riittääkö kokemusperäinen opiskelijakeskeisyys, kun haetaan uusia välineitä elämänmuu. tosten hallintaan? laita?

Kysymyksiä on monia. Miten on vastausten

\section{LÄHTEET}

Alanen, A. 1985. Johdatus aikuiskasvatukseen. Helsinki: Yleisradio.

Cohen, I. 1989. Structuration theory. London: MacMillan.

Giddens, A. 1984a. The constitution of society. Cambridge: Polity Press.

Giddens, A. 1984b. Yhteiskuntateorian keskeisiä ongelmia. Keuruu: Otava.

IImonen, K. 1990. Rakenne Anthony Giddensin strukturaatioteoriassa. Sosiologia 27, 4, 297-307.

Kankanen, K. (nyk. Poutanen) 1990. Työväenopistoopiskelun juuret aikuisopiskelijan elämässä. Helsingin yliopisto, sosiaalipolitiikan laitos, pro gradu-tutkielma.
Kauppi, A. 1988. Opettajien kouluttamisesta opetustyön kehittämiseen. Aikuiskasvatus 8, 4, 14-21.

Leahey, J. 1989. The co-constitution of knowledge issued from qualitative research interviews. Paper presented in the Eighth International Human Science Research Conference. University of Aarhus.

Levinson, D.L. 1978. Seasons of a man's life. New York: Plenum.

Merriam, S. 1978. Middle age: A review of the literature and the implications for the educational intervention. Adult Education, 29, 1, 39-54.

Mezirow, J. 1990. Fostering critical reflection in adulthood. San Francisco: Jossey Bass.

Roos, J.-P. 1988. Elämäntavasta elämänkertaan. Helsinki: Tutkijaliitto. 